\title{
Neonatal diabetes in Wolcott-Rallison syndrome: a case report
}

\author{
Can Thi Bich $\mathrm{Ngoc}^{1 *}$, Vu Chi Dung ${ }^{1}$, Sarah Flanagan², Sian Ellard ${ }^{2}$ \\ From 7th APPES Biennial Scientific Meeting \\ Nusa Dua, Bali. 14-17 November 2012
}

Wolcott-Rallison syndrome (WRS) is a rare autosomal recessive disorder characterized by the association of permanent neonatal or early-infancy insulin-dependent diabetes, multiple epiphyseal dysplasia and growth retardation, and other variable multisystem clinical manifestations. In the present study, we analyzed the EIF2AK3 gene in a 64 day-old-girl WRS patient and his parents to study the clinical features, the mechanism for genetic onset of WRS and provide credible genetic counseling for prenatal diagnosis in his family. Based on analysis of a 64 day-oldgirl's clinical symptoms associated with biochemical examination, the diagnosis of WRS was therefore made. Genomic DNAs were extracted from peripheral blood leukocytes from the patient and her parents with their informed consent for genetic studies. The coding and flanking intronic regions of the EIFAK3 gene was analysed by sequencing. In a result, the patient had gestation age of 41 weeks, birth weight of $3200 \mathrm{~g}$, and onset of the disease at 64 days of age. She was admisted with the features of convulsion, anemia, jaundice, diabetic ketoacidosis with $\mathrm{pH}$ of $7.27, \mathrm{HCO}_{3}{ }^{-}$of $17.8 \mathrm{mmol} / \mathrm{l}, \mathrm{BE}$ of $-8 \mathrm{mmol} / \mathrm{l}$, blood glucose $42.46 \mathrm{mmol} / \mathrm{l}$, HbA1C $6.5 \%$, total bilirubin $59.2 \mu \mathrm{mol} / \mathrm{l}$, direct bilirubin $29.7 \mu \mathrm{mol} / \mathrm{l}$, AST $3741.2 \mathrm{U} / \mathrm{l}$, ALT 1927 U/l. PCR of CMV, EBV, HAV were negative. Abdominal ultrasound did not find any sign of cholestasis. Sequencing analysis of patient's EIF2AK3 gene has identified a homozygous missense mutation, p.R632W. The parents are carriers of heterozygous EIF2AK3 missense mutation, p.R632W. In conclusion, combining mutation screening of EIF2AK3 gene with clinical manifestations and effective examination may provide a reliable diagnostic method for patients.

National Hospital of Pediatrics, Hanoi, Vietnam

Full list of author information is available at the end of the article

Authors' details
${ }^{1}$ National Hospital of Pediatrics, Hanoi, Vietnam. ${ }^{2}$ Royal Denvon and Exter
NHS Healthcare Trust, Exeter, UK.

Published: 3 October 2013

doi:10.1186/1687-9856-2013-S1-P4

Cite this article as: Ngoc et al: Neonatal diabetes in Wolcott-Rallison syndrome: a case report. International Journal of Pediatric Endocrinology 2013 2013(Suppl 1):P4.
Submit your next manuscript to BioMed Central and take full advantage of:

- Convenient online submission

- Thorough peer review

- No space constraints or color figure charges

- Immediate publication on acceptance

- Inclusion in PubMed, CAS, Scopus and Google Scholar

- Research which is freely available for redistribution
C Biomed Central

\section{Biomed Central}

(c) 2013 Ngoc et al; licensee BioMed Central Ltd. This is an Open Access article distributed under the terms of the Creative Commons Attribution License (http://creativecommons.org/licenses/by/2.0), which permits unrestricted use, distribution, and reproduction in any medium, provided the original work is properly cited. 